\title{
浅谈党政领导干部经济责任审计存在的问题及对策
}

张献房 胡勇战 杨德梁

郑州审计中心

DOI:10.32629/ej.v2i5.246

[摘 要] 党政领导干部经济责任审计是一件重要的事情, 是对领导千部的监督和勉励, 也是对人民群众的保障, 能够避免和惩 治腐败行为,为人民服务,真正让人民群众感受到公平公正。然而,在实际工作中,党和政府的领导干部仍面临经济责任审计工作 的一些难点问题,如何解决这些难点问题,它的关键是推进党和政府的领导千部科学发展的经济责任审计,对此, 我们进行了以 下的探讨。

[关键词] 经济责任审计; 问题; 对策

制定和发展经济责任审计, 以满足中国治理, 俗话说, 没 有规矩不成方圆, 在生活中, 总会有一些条条框框的规矩来 约束我们的行为, 领导干部也不例外, 并且更要以身作则。正 是有了这些规矩, 才会让我们得生活更加和谐幸福。对党政 领导干部经济责任审计有利于加强对领导干部的监督与管 理, 有利于促进建立廉洁的政府, 然后实施监督管理制度。

\section{1 经济责任审计中存在的问题}

1. 1 审计监督不完善

对党政领导干部和国有企业领导进行的经济责任审计 工作虽然开展得比较早, 但总体发展不均衡, 一些地方还没 有真正开展起来, 开展起来的地方大部分也仅仅是在县级以 下。这使得部分地区人民群众的保障就受到了影响, 无法达 到党政领导干部经济责任审计的普遍性, 无法及时查处和纠 正违法违规案件和领导干部, 这不利于促进中国的发展和改 革开放道路的实施, 不利于加强党的廉政建设, 在人民群众 心中的形象也会崩塌, 因此, 审计监督的完善与审计监督的 普遍性是极为重要的 ${ }^{[1]}$ 。

1. 2 缺乏统一的经济责任评价标准

影响金融和财务收支和单位的经济活动的因素是多样 的和复杂的, 因此, 对于被审计领导干部的工作要求与经济 责任需要有认真、严格、谨慎、准确的认知并被审计领导干 部的优点和缺点进行准确评估。由于在实际处理中具体的责 任标准与界限很难划分清楚, 这就使得一些干部钻漏洞, 使 得审计工作的进行出现阻碍与停滞, 因此, 建立统一的经济 责任评价标准有很大的意义。

1.3 审计成果转化滞后

目前, 会出现领导干部的经济责任审计被重新审计, 这 是一次“放行”的重新审计。审计过程中, 有雇主与审计失去 联系的情况, 即使审计存在问题, 也很难让当事方承担责任。 审计结果转换的严重滞后削弱了审计监督职能, 直接影响了 领导干部离职后对经济责任的审计。

1.4 个别审计人员素质不高

由于审计人员的工作能力, 知识储备, 智商水平是有限 的, 或者是因为工作作风不严谨, 非主观因素, 如在实施审计
程序中不规范, 以及未在审核时间内赶到等原因, 使得审计 人员虽然有良好的愿望, 客观地反映了问题的本质, 但是也 造成了泄漏评论或误判的后果。另一方面, 由于审计师或他 们自己有图片, 或其他人有支持, 或者领导有 “嘱”, 违反原 则和审计纪律的目的是帮助被审计对象伪造, 或进行人工审 计, 甚至更多权力货币交易, 这些都是已知和承诺的故意行 为, 严重影响审计结果的公平性和公正性 ${ }^{[2]}$ 。

\section{2 加强经济责任审计工作的对策}

2.1 全面提高审计人员素质

针对经济、审计责任大, 要求高, 涉及的问题比较复杂, 审计风险较大等特点, 强化审计队伍建设, 加大教育和培训 经费的投入。俗话说活到老, 学到老, 不管身在何处, 位居何 位, 都要提高素质, 为人民服务。审计人员更要不断学习, 了 解当下的政治制度, 经济发展方向等, 加强自己的学习能力, 改进自己的作风, 讲究务实, 努力提高工作人员的办事效率 与服务质量, 真正做到为人民服务, 对审计工作的健康发展 也是百利而无一害。对于审计人员的选取也要经过层层把关, 严格考察审计人员的知识水平、审计能力等, 提前观察其作 风, 人品, 心态等问题, 绝不录用滥笔充数之人。

\section{2抓住经济责任审计的重点}

对于经济责任审计问题, 需要重点注意四个方面。一是 经济活动的合法性, 在举办的经济活动中, 要着重考察经营 成果和财务活动等经济绩效, 是否是必要的经济活动, 是否真 实举办过, 全面反映受审核方在任期内的指标完成情况。二是 资产的真实性, 审计会计资料是否能真实的表明其内部财务 收支, 是否符合标准等。三是抓住重大经济决策并进行关键 审计。四是掌握单位内部控制制度的建立, 进行重点审核。

2. 3 保证审计工作的针对性和有效性

目前, 经济责任审计尚未真正实现 “先审计后离任”, 往往是领导干部已经调任才请审计部门去审计, 给审计工作 带来了一定的难度。针对这种现象, 首先是要大力推进领导 干部的审计任期内, 进行过度的非处方监管, 改变辞职审计 作为中间审核, 移动经济责任审计前避免过度的非处方的变 化和人事变动, 避免丢失审计证据; 第二, 有必要加强与人事 


\section{商业银行信用风险管理浅析}

周秋文

中国建设银行湖南省分行

DOI:10.32629/ej.v2i5.251

[摘 要] 信用风险是商业银行面临的最主要风险, 贯穿于银行经营管理过程始终。十九大报告指出我国商业银行要 “守住不 发生系统性金融风险”, 其中信用风险管理是关键。与西方发达国家相比, 我国商业银行信用风险管理体系尚不完善,管理研究 起步较晚,外部环境变化较快, 风险管理技术手段和水平相对落后,因此研究商业银行如何加强信用风险管理、全面提高资产质 量显得尤为重要。本文从“贷款流程管控”、“评级管理”、“信贷文化建设”三个角度入手,结合目前商业银行信用风险管理 现状,提出有针对性的、切实可行提高商业银行信用风险管理水平的对策建议,进一步研究如何推动我国商业银行加强风险管 控、提升经营管理能力。

[关键词] 商业银行; 信用风险; 信贷文化建设

十九大报告提出, 我国经济由高速增长阶段转向高质量 发展阶段, 服务实体经济、防控金融风险、深化金融改革是 当前金融工作的三项基本任务。冊庸置疑, 商业银行在经济 金融发展中有着举足轻重的地位, 如何做好银行的风险管理 对于防控系统性金融风险具有重大意义。商业银行在经营管 理过程中面临许多风险, 譬如市场风险、信用风险、操作风 险、声誉风险、法律风险等, 其中又以信用风险最为普遍。 信用风险又称违约风险, 是指借款人因种种原因, 不愿或无 力履行合同条件而构成违约, 致使银行遭受损失的可能性。 信用风险主要发生在贷款、担保、承兄和证券投资等表内外 业务中, 这里主要以信贷资产为例, 进一步探讨商业银行的 信用风险管理。

\section{1 贷款全流程管控}

全流程管控, 即 “贷前、贷中、贷后”三个环节, 根据贷 款新规也可细分为受理、调查、风评、审批、签约、发放、
支付、后管和处置九大环节。首先, 做好贷前管理, 通过尽职 调查掌握企业的真实情况, 明确客户投向, 引导贷前客户选 择, 重点支持绿色信贷、普惠金融、先进制造业和现代服务 业领域, 实行信贷客户名单制管理机制, 促进信贷结构优化。 其次, 做好贷中管理, 以审慎性原则为抓手做好押品评估, 严 格审批手续、落实放款条件、把握贷中关键环节和关键风险 点, 推进风险管理向 “全面管” “主动管” 转变, 按照全面风 险管理要求, 商业银行既要落实主体责任、领导责任, 同时也 要落实管理责任和直接责任, 压实各岗位、各环节风险管控 职责, 发挥岗位制衡作用, 实现风险联防联控。最后, 做好贷 后管理, 主要包括押品的动态管理、雷达预警系统响应、企 业贷后实地调研和不良资产处置, 前三者针对潜在风险化解, 逐个梳理潜在风险客户, 仔细研究, 摸清原因, 有针对性地采 取风险化解措施; 后者针对已暴露风险化解处置, 根据风险 严重程度, 一户一策或一户多策, 因地制宜采取风险缓释措施、
部门的组织, 当出现人员变动, 有领导需要调任的时候, 需要 提前对领导进行审计, 并在审计过关后才能调任, 这样才能 更好地发挥审计工作在人员变动方面的作用, 这样使得审计 工作更加谨慎, 对人员的把控方面也更加严格 ${ }^{[3]}$ 。

\section{4注重部门之间协调配合}

经济责任审计是新时期党风廉政建设和基层组织建设 的重要任务, 各个部分之间也要积极配合, 互相协调, 互相沟 通, 互相帮助, 这样有利于促进共同发展, 部门间密切配合, 资源共享更有利于审计工作的顺利进行。同时, 审计结果将 向公众公布, 并由人民接受审查和监督。

\section{5 健全审计评价标准体系}

党政领导干部经济责任审计评价的标准应当由各级 纪检监察机构, 组织人员和审计部门共同研究制定。由于 审计工作的重要性, 对党政领导干部经济责任审计结果也 要公平公正, 有理有据, 所以, 对于审计评价标准也要有合 理性, 专业性, 科学性和可操作性。合理的制定标准, 不可
有模糊的界限, 不可随意辨别, 在操作中准确, 直观地进行 审计评估。

\section{3 结束语}

解决经济责任审计中存在的问题和加强经济责任审计 工作的对策正逐渐成为审计机关的主要任务。各级经济秩序 的管理, 规范领导干部经济行为, 促进领导干部勤政廉政都 是继续努力的方向, 我们要突出审计重点, 提高审计效率。防 止机构的分级管理腐败, 同时加强主动监督, 以满足日益变 化的经济责任审计的需要。

\section{[参考文献]}

[1]贝翔.加强党政领导干部同步审计健全权力运行制 约和监督机制[J].中国审计,2015(07):34-35.

[2]李坤,梁晓阳.经济责任同步审计存在的问题及改进 建议[J].中国审计,2015(07):36-37.

[3] 霍嘉. 县区党政领导千部经济责任审计风险应对措施 [J].江苏审计,2015(02):124-125. 